\title{
Law and Justice in the Discussion of Military Conflicts in Russian Secondary School World History Textbooks
}

\author{
Tatyana Kudryavtseva \\ Vladimir Zemlyanicyn
}

Herzen State Pedagogical University of Russia, 191186, 48, Moika emb., Saint Petersburg,Russia

\section{Doi:10.5901/mjss.2015.v6n6p84}

\begin{abstract}
The paper analyzes the treatment of military conflicts and their legal resolution in current Russian history textbooks for secondary school (grades 5-9), particularly in regard to shaping the students' notions of "just war", "just peace" as well as the legitimacy of making certain decisions in the international relations sphere. The conducted analysis allows us to claim that Russian secondary school world history textbooks only touch upon the issues of justice and law. The textbooks are critical of military ways of resolving international conflicts, and declare the importance and the fundamental possibility of diplomatic solutions. They really shape the concept of a just war, but the legal evaluation of the opposing parties' actions is practically inexistent.
\end{abstract}

Keywords: textbooks, history, secondary school, war, peace, justice.

\section{Introduction}

The Federal State Education Standard for secondary education (hereinafter FSES) that is to become mandatory for all Russian schools as of September 1, 2015, contains requirements for personal competency results of education. This personal competency element contains a significant ideological component. For example, the students who have mastered the secondary education program have to demonstrate patriotism, tolerance, ethical behavior and competence in solving moral dilemmas (Federalnyj gosudarstvennyj obrazovatel'nyj standart dlja osnovnogo obshchego obrasovanja. Retrieved May 30, 2015, p.5-6). Thus the modern Russian education increases the significance of the historical science's character-building potential and its role in the self-identification process based on the exploration of humankind's historical experience. The chief burden is certainly placed upon the Russian history course, however, it is closely interlaced with the world history course, and also implies the reinforcement of the character-building component in the world history courses.

\section{Objectives, Methodology and Research Design}

While we are not aspiring to a comprehensive analysis of the current world history textbooks' morale-building potential, we will attempt to discern the ways in which world history courses shape the notions of law and justice in international relations and military conflicts. Our attention to this particular agenda is bound by the fact that the issues of making certain decisions in international relations and their relationship to historical justice are especially volatile in the current discourse within Russia, which, directly or vicariously, has undoubtedly impacted the way in which history is taught in school. From this point of view it is crucial to determine how exactly these issues are covered in the educational materials aimed at Russian students. The object of our analysis are the world history textbooks from the Federal index of textbooks recommended for use in the state-accredited educational programs of the basic elementary, middle and secondary education (Federalnij perechen' uchebnikov, recomenduemykh $k$ ispol'sovaniju pri realisatsii imejushchikh gosudarstvennuju akkreditatsiju obrazovatel'nykh programm nachal'nogo obshchego, osnovnogo obshchego i srednego obshchego obrasovanja. Retrieved May 30, 2015, p.64-67). Since the mastering of the FSES-based educational programs will be specifically based on the textbooks listed in the Federal index, the source base for our research seems sufficient for obtaining objective results. 


\section{Discussion of the Research Outcomes}

The following ancient history (5th grade) textbooks are analyzed: A.A.Vigasin et al. ("Prosveshchenie") as well as T.P. Andreevskaya et al. ("Ventana-Graf"). The latter textbook's Ancient East chapter (written by Andreevskaya) practically excludes from its pages the issues of international relations, military conflicts and their settlement, concentrating on daily life, culture and religion. For example, the chapter on Ancient Egypt informs the students in a single sentence about all of the following: Thutmose III conquered Nubia, Palestine and Syria, and Ramses II fought a war against the Hittite kingdom, which resulted in a peace agreement, "one of the first surviving peace and non-aggression treaties" (Vigasin, A.A., et al, 2010, p.45-46). The Assyrian kingdom section is slightly more informative: there is an emphasis on the cruelty of their wars of conquest and their abuse of the conquered people (Andreevskaya, T.P., et al., 2012, p.74-75); the same details are accentuated in the textbook by A.A.Vigasin et al. (Vigasin, A.A., et al, 2010, p.84). The "Pharaohs' military campaigns" chapter emphasizes the war's hardships (Vigasin, A.A., et al, 2010, p.46-47). One of the most extensive accounts in the 5th grade textbooks is given of the war of Jews and Philistines, it is outlined in the Biblical tradition (Vigasin, A.A., et al, 2010, p.78-80, p.85-86), with a certain hidden empathy towards the ancient Jews' fight with their external enemies.

The ancient Greece chapters of the textbooks devote much attention and space to the Greco-Persian wars (Andreevskaya, T.P., et al., 2012, p.146-154; Vigasin, A.A., et al, 2010, p.154-163). Both the cited facts and the emotional tone shape the students' ideas of courage and heroism as exemplified by king Leonid and the 300 Spartans, and are conducive to the perception of this war as a fair one for the Greeks, as they were defending their freedom and independence. The 449 B.C. truce between Greek cities and Persia is only mentioned in the textbook (Andreevskaya, T.P., et al., 2012, p.153). Both textbooks mention Demosthenes' patriotic fight with the imminent Macedonian hegemony (Andreevskaya, T.P., et al., 2012, p.189; Vigasin, A.A., et al, 2010, p.188). The exhaustive account of Alexander's Eastern campaign points out its invasive nature and emphasizes the Macedonian king's personality (Andreevskaya, T.P., et al., 2012, p.191-196; Vigasin, A.A., et al, 2010, p.190-195).

In the chapters devoted to ancient Rome the wars led by the Romans are often at the core of the narrative; peace negotiations are also mentioned (i.e. Pyrrhus' proposal for peace and the passionate speech by Appius Claudius the Blind in response to the Epirus king's envoy's address to the Senate (Andreevskaya, T.P., et al., 2012, p.220; Vigasin, A.A., et al, 2010, p.211), as well as Rome's peace agreements with Carthage following the First (Andreevskaya, T.P., et al., 2012, p.228), and the Second Punic wars (Vigasin, A.A., et al, 2010, p.220). The wars which resulted in Rome becoming the master of the Western, and, consequently, the Eastern Mediterranean are unanimously considered invasive by the authors of the former textbook (Vigasin, A.A., et al, 2010, p.225); while the latter (the author of the ancient Rome chapter is Belkin) treats it in a more subtle manner as he mentions that, following Rome's victories over its enemies, it became the most powerful state in the Mediterranean (Andreevskaya, T.P., et al., 2012, p.236).

Separate chapters focus on civil wars (Andreevskaya, T.P., et al., 2012, p.256-270; Vigasin, A.A., et al, 2010, p.230-247). Belkin points out that civil wars "are the most frightful events that can happen in the history of a country" (Andreevskaya, T.P., et al., 2012, p.256); the students are then asked to speculate and find an answer to the question of why that is indeed the case. Meanwhile, both textbooks emphatically describe the Spartacus' uprising, sparked by the cruel treatment of slaves (Andreevskaya, T.P., et al., 2012, p.234-238; Vigasin, A.A., et al, 2010, p.253-255). Hence, while civil war is condemned as murderous and fratricidal, the emotional account of the causes and the course of the Spartacus' rebellion implies the righteousness of the slaves' fight for their freedom.

The issues of international relations have not received extended coverage in the 6th grade medieval history textbooks. Certain sections dedicated to international relations are missing from the textbooks on this particular historical period and, as a matter of fact, the treatment of medieval foreign policy issues is limited to two topics, namely, the Crusades and the Hundred Years' War. This situation is to a significant extent accounted for by the very specific nature of medieval foreign affairs. According to N.I. Basovskaya, a distinguished Russian medievalist, "the sharp distinction drawn between 'domestic' and 'foreign' policy of a feudal state is merely a convention akin to that of the 'horizon line' " (Basovskaya, N.I., 2002, p.43). Thus, the close entanglement of domestic and foreign policy matters in medieval history textbooks is not, in our opinion, a deliberate simplification utilized by the authors to adapt the content for the 6th grade students' perception, but an objective reflection of the developing trends in modern medieval studies.

As they reveal the causes of the Crusaders' movement, the authors of the school textbooks attempt to demonstrate the multiple factors involved and present the underlying motives of the Crusades as indeed righteous from a medieval European's point of view. Specifically, the textbook by E.V. Agibalova and G.M. Donskoi mentions that "the Crusaders were convinced that they are going to fight for a holy cause" (Agibalova, E.V., et al, 2012, p.147), while L.V. Iskrovskaya et al. underscore the Crusaders' pursuit to "free their 'brothers in faith' from opression" (Iskrovskaya, L.V., et al., 2013, 
p.50). Coincidently, the Crusaders' modus operandi is unambiguously condemned, as is the IVth Crusade led against the Byzantine Empire. The textbook by E.V. Agibalova and G.M. Donskoi even offers the following question for the students' consideration: "Propose the possible reasons for the IVth Crusade often being called 'the disgrace of the Crusades' " (Agibalova, E.V., et al, 2012, p. 149). Only the textbook by M.A. Boicov and R.M. Shukurov informs the students that the IVth Crusade participants had legal basis for interfering in the Byzantine Empire's domestic affairs, as the dethroned Byzantine emperor Isaac II had appealed to them for help (Boicov, M.A., at al., 2013, p.136).

As far as the assessment of the Hundred Years' War's causes is concerned, there are two distinct points of view to be found in textbooks. One group of authors attributes the causes of the major international conflict of the Middle Ages to its viability for the states involved - without regaining Aquitaine France's unification could not be completed, but this province was an important source of income for England, and, therefore, its loss contradicted the interests of the English state (Agibalova, E.V., et al, 2012, p.167). Another group of authors emphasizes the legal aspect of the issue - being the grandson of Philippe IV the Beautiful, Edward III could lay claim to the French throne, but "the handover of the crown via female lineage was considered unlawful in France" (Iskrovskaya, L.V., et al., 2013, p.169). In any case, none of the textbooks conclusively condemn of one side's actions, and justification of the other in the process of triggering off the conflict.

The textbooks' authors are also univocal in their legal assessment of the Treaty of Troyes of 1420 and Carl VII's antagonism to it. The truce signed at Troyes is characterized as humiliating for France (Iskrovskaya, L.V., et al., 2013, p.172), and Carl VII's rights to the French throne are considered absolutely legitimate (Agibalova, E.V., et al, 2012, p.172; Iskrovskaya, L.V., et al., 2013, p.172). This notion, characteristic for the patriotic viewpoint in French historical scholarship, does not appear to be indisputable (Zemlyanicyn, V.A., 2005, p.11-18). It is, however, rather symptomatic, as the formal, legal side of the problem becomes secondary to the principle of "national justice".

Wars of conquest led by the Mongols, the Ottoman Turks and Tamerlane incur definitive and unanimous condemnation in medieval history textbooks. The authors mention that the Mongol and Ottoman conquests induced economic desolation of the invaded countries, hindered the cultural development of the subjugated peoples (Agibalova, E.V., et al, 2012, p.209; Iskrovskaya, L.V., et al., 2013, p.209, 269). In order for the students to form a conscious critical notion of Tamerlane's expansionist politics Iskrovskaya offers the following task: "Give an evaluation of Tamerlane's endeavor to make Samarkand the most beautiful city. Do you consider his destruction of other cities justified in order to realize his dream?"

The early modern history course, studied in 7th and 8th grades, allots separate chapters to international relations issues, since this historical epoch is characterized by the genesis of an international relations system, and due to the fact that the students are now able to explore the basics of international law theory in view of their age. Alongside with this, modern history textbooks cover a number of international relations issues in paragraphs related to specific countries' development. This fact corroborates the idea that the separation of domestic and foreign policy issues in modern historical science is more of a convention than anything else.

Collision of the European states' trade interests', battles for the colonies, dynastic interests, religious factors, the Ottoman factor are all named as major causes of the early modern period wars (Dmitrieva, O.V., 2012, p.161-164). Meanwhile, the textbook by A.Y. Yudovskaya et al. designates the conflict of state interests, which "most often used the campaign for the 'integrity of faith' as a pretext" (Judovskaja, A.Y., et al., 2013, p.169), as the true reason for the military conflicts of the XVI-XVII Cc. The issue of responsibility for unleashing an international conflict is presented to the students in the textbook by Noskov and Andreevskaya. Here the reasons for the Prague uprising of 1618, which became the starting point of the Thirty Years' War, are found to be rooted in the Hapsburg policy towards Bohemia, as there was religious oppression and "an attempt to deprive the kingdom's population of its privileges" (Noskov, V.V., Andreevskaya, T.P., 2013, p.20). However, none of the current early modern history textbooks give a legal appraisal of the opposing parties' actions in the European wars of the XVI-XVII cc. Yudovskaya also leaves open the issue of responsibility for launching wars for the Spanish and Austrian legacies, while Dmitrieva emphasizes that the main reason behind the war for the Spanish legacy were "Louis XIV insatiable appetites", while the "rise of Prussia led by the ambitious Frederick II to power" is considered the chief threat to the European power balance system (Dmitrieva, O.V., 2012, p. 235, 237).

In their accounts of the French revolutionary wars the textbook authors traditionally justify the French government's actions aimed at protecting the revolutionary order established in France, although they do admit that "the war between revolutionary France and European powers was started by the Girondists, who aimed to strengthen their influence in the course of a victorious war, and Louis XIV, who hoped to regain his prior power" (Judovskaja, A.Y., et al., 2013, p.243244).

The evaluation of the Napoleonic wars in early modern school history textbooks is highly ambiguous. On one hand, the authors recognize the fact that "Napoleon abolished feudal duties in the conquered territories, stripped the church and 
monasteries of the rights to certain dues, instituted laws that should have to an extent strengthened individual rights" (Judovskaja, A.Y., et al.,2013, p.259). On the other hand, the Napoleonic wars are characterized as wars of conquest, while the regime established in the conquered territories is defined as occupation (Judovskaja, A.Y., at al., 2013, p.98; Zagladin, N.V., 2010, p.20). There is no unity on the issue of Napoleonic France's conflict with Russia. In the opinion of Yudovskaya, the main reason behind this conflict is Russia's secret violation of the Treaty of Tilsit (Judovskaja, A.Y., at al., 2013, p.103), while Noskov and Andreevskaya consider it to be "the tenacious unwillingness of Alexander I to support Napoleon in stiffening the continental blockade" and "rise to power of the Grand Duchy of Warsaw" (Noskov, V.V., Andreevskaya, T.P., 2013, p.25). Zagladin, in his turn, concludes that Napoleon needed this war in order to "strengthen his authority with new victories and subdue the last large independent state in continental Europe" (Zagladin, N.V., 2010, p.23). Hereby in the first two cases the authors partially recognize Napoleon's demands on Russia as just, even if indirectly. In the third case all responsibility for launching the war is rested fully upon Napoleon.

The Vienna congress decisions are characterized by the textbooks authors as decisively unfair. The authors note that the countries with the leading roles in the congress, namely, Great Britain, Austria, Prussia and Russia "completely disregarded other European countries' interests" (Judovskaja, A.Y., at al., 2013, p.107), while "the Congress of Vienna decisions on territorial issues served exclusively the monarchs' interests rather than those of the people who fought against Napoleon" (Zagladin, N.V., 2010, p.32). It is in the injustice of the congress resolutions that the authors see the roots of the conflicts that ensued in Europe (Zagladin, N.V., 2010, p.32).

The issues in international relations linked to the Crimean war are considered mainly in the Russian history course. In the world history course these problems are only touched upon. It is, however, rather curious that the authors do not consider the actions taken by Russia in this conflict to be unambiguously just. On the opposite, Zagladin mentions that after the Turkish economy was subordinated by the Western countries, Russia was "apprehensive about losing its influence on its southern neighbor" (Zagladin, N.V., 2010, p.200).

In respect to the international relations in the 2 nd half of the XIX century, we should direct our attention to the authors' evaluation of the causes and the results of the Franco-Prussian war of 1870-1871. While both Napoleon III and Bismarck are held responsible for the initiation of the war, the conditions of Treaty of Frankfurt, which ended the conflict, are considered unfair in the textbooks. The authors emphasize the fact that the conditions of the agreement unavoidably led to the rise of revanchist sentiment in France, and therefore could not provide for a lasting peace in Europe (Judovskaja, A.Y., at al., 2013, p.164; Zagladin, N.V., 2010, p.79).

The colonialist politics pursued by the European states is unanimously condemned by the textbook authors as unfair, unlawful and inhumane. According to Zagladin, the states that were subjected to the Europeans' expansionist actions "were turned into colonies and markets for goods from the industrial states, their interests were no longer taken into consideration" (Zagladin, N.V., 2010, p.4). The authors mention that Russia participated in colonial division of China and Persia along with the European states (Zagladin, N.V., 2010, p.188, 203; Noskov, V.V., Andreevskaya, T.P., 2013, p.294).

International relations and military conflicts hold a significant place in the modern history textbooks for the 9th grade; this can be doubtlessly attributed to the two large-scale events of the XX century that took a catastrophic toll and had far-reaching consequences - the two World Wars. The textbook "World history. Modern history. 9Th grade" (by O.S. Soroko-Cupa, A.O. Soroko-Cupa) begins its account with World War I (which appears logical), while the "World History" textbook for 9th grade" (by V.L. Heifets et al.) begins with "The world after World War I" chapter. O.S. and A.O. SorokoCupa lay the responsibility for unleashing the war on all of its chief participants, with an exception made for Serbia and Belgium, the countries for which the war was a "just" one (Soroko-Cupa, O.S., Soroko-Cupa, A.O., 2012, p.40). It is noted that the conditions of the Treaty of Versailles were "predatory and devastating for Germany and its allies", Germany is recognized as the sole perpetrator of the war, and Soviet Russia, which lacked representation in the Paris peace conference, "was not only excluded from the creation of a post-war peace structure, but was also subjected to intervention by the Western countries" (Soroko-Cupa, O.S., Soroko-Cupa, A.O., 2012, p.52, 54). The textbook by V.L. Heifets et al. enumerates several of the treaty's clauses, and consequently emphasizes that "after the war neither Russia nor its army were fated to be in the ranks of the winners", although Russia was the one to suffer the greatest losses (Heifets, V.L., et al., 2012, p.9). Although the fairness of the Versailles treaty is not examined in either textbook, students may reasonably get an impression of the injustice inherent in the Versailles-Washington system as a whole and in this peace treaty in particular, injustice towards both Germany and Russia. Both textbooks emphasize the importance of the League of Nations' emergence for the development of the international legal framework, but at the same time the fragility of the post-World War I system is pointed out (Soroko-Cupa, O.S., Soroko-Cupa, A.O., 2012, p.53-54; Heifets, V.L., et al., 2012, p.9-10). The victor countries reaped the benefits of the new world order; O.S. and A.O. Soroko-Cupa resemble their Soviet predecessors in stigmatizing the "imperialist predators" for carving up their colonial trophies through the 
mandate system (Heifets, V.L., et al., 2012, p.10,54).

The international relations of the 1920s-1930s are discussed in country-specific paragraphs (i.e. USA, Great Britain, France, etc.) as well as in separate paragraphs. It's encouraging that both textbooks found it important to mention the 1928 Kellogg-Briand pact that proclaimed the renunciation of war as a dispute settlement method (Soroko-Cupa, O.S., Soroko-Cupa, A.O., 2012, p.66; Heifets, V.L., et al., 2012, p.82).

The collapse of the Versailles-Washington system, as manifested by the breach of the relevant treaties, is accounted for as the consequences of the 1929-1933 world economic crisis (Soroko-Cupa, O.S., Soroko-Cupa, A.O., 2012, p.33). The blame for the revision of the international relations system and the unconcealed aggression is assigned to Japan, Italy and Germany; the "appeasement policy" that led to the "Munich agreement" is called "naive and mad", "a synonym for betrayal and the peak of opportunistic concessions on the part of England and France" (Soroko-Cupa, O.S., Soroko-Cupa, A.O., 2012, p.136). The textbook's authors don't provide a legal evaluation of the German-Soviet NonAggression Treaty and the classified Molotov-Ribbentrop protocols, and, accordingly, to the USSR's participation in partition of Poland and its conduct in regard to the Baltic States. They refer to the fact that historians have not reached a consensus on the subject - some invoke the particular historic situation, and approve of these documents, still others regard them as a manifestation of imperial politics and consider them erroneous (Soroko-Cupa, O.S., Soroko-Cupa, A.O., 2012, p.138). The questions that follow avoid this dubious topic, but the students are asked to contemplate the following question: "The Munich deal of 1938 - betrayal or mistake?"

Paris and London lack of foresight to understand that the world is tumbling towards a new war, along with the USA's isolationist position led to the aggressor not being actively countered according to V.L. Heifets et al. The USSR's antifascist stand is strongly emphasized (assisting the Spanish Republican government, asserting the idea of collective security); the "Munich deal" is pronounced "the most disgraceful page in the pre-war international relations" (Heifets, V.L., et al., 2012, p.84-87). Although the authors mention the fact of the signing of the secret protocols to the German-Soviet Non-Aggression Treaty, they neither give an assessment of these documents, nor mention the Winter War, USSR's exclusion from the League of Nations or the fate of the Baltic States. Such an omission probably arises from the authors' reluctance to touch upon complicated controversial issues that concern national history. Thus the students are to form a notion that the blame for unleashing the World War II rests exclusively on the Axis Powers (Berlin-Tokyo-Rome) and the "appeasers", namely London and Paris, who indulged them.

The Soviet army's entry into Poland on September 17 is barely mentioned as an event in USSR's foreign policy in the O.S. and A.O. Soroko-Cupa's textbook (Soroko-Cupa, O.S., Soroko-Cupa, A.O., 2012, p.139), while V.L. Heifets et al. go into more detail: this decision was made by the Soviet government in anticipation of the Hitler's army possibly going further than the demarcation line specified in the secret protocol (Heifets, V.L., et al., 2012, p.106).

The formation of the anti-Hitler coalition and the corresponding regulatory support are given consideration by both textbooks, and while the Teheran conference is covered in two sentences by the O.S. and A.O. Soroko-Cupa's textbook (Soroko-Cupa, O.S., Soroko-Cupa, A.O., 2012, p. 148), the textbook by V.L. Heifets et al. devotes a special section to it (Heifets, V.L., et al., 2012, p. 126). It is pointed out that "the Teheran conference demonstrated that efficient cooperation was possible between countries with different political orders" (Heifets, V.L., et al., 2012, p.126). The reports of the Crimean and the Potsdam conference and their roles in the post-war world order are rather detailed. Special attention is given to the Yalta conference resolution to create the United Nations (Soroko-Cupa, O.S., Soroko-Cupa, A.O., 2012, p.149; Heifets, V.L., et al., 2012, p.140). The fact that countries with different systems of social relations have found ways to coordinate their actions is regarded as one of the chief results of the World War II (Soroko-Cupa, O.S., Soroko-Cupa, A.O., 2012, p.153); as for the effect on international relations structure and global politics - it was the creation of a bipolar world and the confrontation of two superpowers (Soroko-Cupa, O.S., Soroko-Cupa, A.O., 2012, p.153; Heifets, V.L., et al., 2012, p.139). It is pointed out that the USSR suffered the heaviest casualties, and that it was the principal contributor to the victory over the fascist Germany (Soroko-Cupa, O.S., Soroko-Cupa, A.O., 2012, p.153; Heifets, V.L., et al., 2012, p.138-139). The students are led towards the conclusion that the Soviet state's growing international prestige and its transformation into a world superpower are fair and justified, as they were settled with a huge price.

The post-war world appears as the time of the two superpowers' competition, of the confrontation between the two military and political blocs - NATO and the Warsaw agreement, and it is acknowledged that nuclear weapons acted as a military conflict deterrent (Soroko-Cupa, O.S., Soroko-Cupa, A.O., 2012, p.162; Heifets, V.L., et al., 2012, p.263). The success of the detente policy (since the end of the 1960s) was determined not only by the arrival at nuclear parity and by the political will of the leaders of countries involved, but also by a series of international agreements: START-1 (Strategic Arms Reduction Treaty), START-2 and ABMT (Anti-ballistic Missile Treaty), while the principal achievement of "detente" was the Conference for Security and Cooperation in Europe in 1975 and the Helsinki Accords signed as a result (SorokoCupa, O.S., Soroko-Cupa, A.O., 2012, p.267; Heifets, V.L., et al., 2012, p.264-265). 
In the 1990s the USA remained the only superpower; the account of modern US politics is of an accusatory nature, as it assumes the role of an international arbitrator, supersedes the UN in resolution of international conflicts, actively pursues the course of NATO expansion to the east, proclaims its right to interfere in other countries' affairs (SorokoCupa, O.S., Soroko-Cupa, A.O., 2012, p.204, 274; Heifets, V.L., et al., 2012, p.162,272-273). "This concept stands against the idea of a multipolar world, which is backed by Russia, India, China, and others" (Soroko-Cupa, O.S., SorokoCupa, A.O., 2012, p.204).

\section{Conclusion}

The first world history textbooks (5th grade) inform the students of the cruelty and inhumanity characteristic of wars and introduce the notion that wars may not only be invasive, but also fair. Civil wars are particularly condemned. Unfortunately, the topic of peace treaties or negotiations is very scantily represented in the textbooks examined: for instance, the textbook by A.A.Vigasin et al. altogether ignores the international peace treaty between Egyptian pharaoh Ramses the II and Hittite king Hattusili - the first historically documented peace, non-aggression and cooperation treaty in world history. The peace treaties established by the Greeks, and, consequently, the Romans, are at best mentioned in passing.

The issues of foreign policy are practically merged with ones of domestic policy in the 5th and 6th grade textbooks. The early modern history textbooks (7th and 8th grades) put a greater emphasis on international relations, there are separate paragraphs dedicated to this topic. However, no legal evaluation is given to the countries' activities on the international arena, while ethics-related reviews are incidental and ambiguous.

Issues of peaceful settlements, treaties and the corresponding conferences hold a much more prominent place in the early modern history textbook (9th grade). The two World Wars are the central subjects. The unfairness and the fragility of the Versailles-Washington system are acknowledged. The responsibility for launching the World War II is placed completely on the Axis Powers, and to a certain degree on the Western politicians and their "appeasement of the aggressor". The issue of the Stalin's diplomacy's responsibility (including the partition of Eastern Europe into spheres of influence between USSR and Germany) is not examined; certain difficult questions simply aren't raised due to the complexity of their evaluation. The importance of dialogue between countries with different social orders is emphasized. A negative assessment is given to the unipolar world and the role of the USA in the modern world due to its attempt to take the place of the UN and similar organizations, where various countries can reach a consensus.

Hence the conducted analysis allows us to claim that Russian secondary school world history textbooks only touch upon the issues of justice and law. The textbooks are critical of military ways of resolving international conflicts, and declare the importance and the fundamental possibility of diplomatic solutions. On the other hand, the textbook shape the concept of a just war, one that is fought for the preservation or the attainment of independence or in defense of territories. Such wars are juxtaposed to invasive and colonial wars, which are univocally condemned. The 9th grade textbooks raise the issues of a country's responsibility for unleashing a war. However, the legal evaluation of the opposing parties' actions is practically inexistent. The rectitude of one or the other side is determined on the basis of the authors' moral and ethical beliefs, which are a priori subjective and depend on their ideological inclinations and political sympathies, rather than being founded on the legal norms of the relevant time period.

In view of the foregoing it can be concluded that modern Russian world history textbooks for secondary schools do not allow the students to form consistent notions of legitimacy and justice of countries' actions in launching or terminating military conflicts. This does not only hinder the students' ability to adequately appraise Russia's conduct in the international arena in historical context (which is absolutely essential to study of national history), but prevents Russian youth from forming their own opinion regarding current international conflicts.

\section{Acknowledgements}

The Paper was created within the project financed by Russian Scientific Fund (RNF - Rossijscij nauchnyj fond) (№ 1418-00390) solved at Herzen State Pedagogical University of Russia

\section{References}

Agibalova, E.V., Donskoj, G.M. (2012). Vseobshchaja istorija. Istorija srednikh vekov. 6 klass [The World history. The history of the Middle Ages: 6th grade]. Moskva: Prosveshchenie.

Andreevskaya, T.P., Belkin, M.V., Vanina, E.V. (2012). Istorija drevnego mira: 5 klass [The History of the Ancient World: 5th grade ]. 
Moskva: Ventana-Graf.

Basovskaya, N.I. (2002). Voobrazhaemaja linija gorizonta: gran' mezhdu vneshnej i vnutrennej politikoj v srednevekovom obshchestve [The imaginary horizon: the line between internal and foreign politics in medieval society]. In Basovskaya, N.I. Cel' istorii - istorija [The goal of history is history] (pp. 35-44). Moskva: RGGU.

Boicov, M.A., Shukurov, R.M. (2013). Vseobshchaja istorija. Istorija srednikh vekov [The World history. The history of the Middle Ages]. Moskva: Russkoe slovo.

Dmitrieva, O.V. (2012). Vseobshhaja istorija. Istorija novogo vremeni. Konec XV - XVIII vek: 7 klass [The World history. The Modern history. The end of the XV-XVIII century: 7th grade]. Moskva: Russkoe slovo.

Federalnij perechen' uchebnikov, recomenduemykh $\mathrm{k}$ ispol'sovaniju pri realisatsii imejushchikh gosudarstvennuju akkreditatsiju obrazovatel'nykh programm nachal'nogo obshchego, osnovnogo obshchego i srednego obshchego obrasovanja [Federal index of textbooks recommended for use in the state-accredited educational programs of the basic elementary, middle and secondary education.] Retrieved May 30, 2015, from http://edu-frn.spb.ru/docs/federal

Federalnyj gosudarstvennyj obrazovatel'nyj standart dlja osnovnogo obshchego obrasovanja [Federal State Education Standard for the basic secondary education]. Retrieved May 30, 2015, from http://standart.edu.ru/catalog.aspx?Catalogld=2588

Heifets, V.L., Heifets, L.S, Severinov, K.M. (2012). Vseobshchaja istorija. 9 klass [The World History: 9th grade]. Moskva: Ventana-Graf.

Iskrovskaya, L.V., Fedorov, S.E., Guryanova, Ju.V. (2013). Istorija srednih vekov: 6 klass [The history of the Middle Ages: 6-th grade]. Moskva: Ventana-Graf.

Judovskaja, A.Y., Baranov, P.A., Vanyushkina, L.M. (2013). Vseobshchaja istorija. Istorija Novogo vremeni. 1500 - 1800. 7 klass [The World history. The Modern history. 1500 - 1800. 7th grade]. Moskva: Prosveshchenie.

Judovskaja, A.Y., Baranov, P.A., Vanyushkina, L.M. (2013). Vseobshchaja istorija. Istorija Novogo vremeni. 1800 - 1900. 8 klass [The World history. The Modern history. 1800 - 1900. 8th grade]. Moskva: Prosveshchenie.

Noskov, V.V., Andreevskaya, T.P. (2013). Vseobshchaja istorija: 7 klass [The World history: 7-th grade]. Moskva: Ventana-Graf.

Noskov, V.V., Andreevskaya, T.P. (2013). Vseobshchaja istorija: 8 klass [The World history: 8-th grade]. Moskva: Ventana-Graf.

Soroko-Cupa, O.S., Soroko-Cupa, A.O. (2012). Vseobshchaja istorija. Novejshaja istorija. 9 klass [World history. Modern history. 9th grade]. Moskva: Prosveshchenie.

Vigasin, A.A., Goder, G.I., Svencickaya, I.S. (2010). Istorija drevnego mira: 5 klass [The History of the Ancient World: 5th grade]. Moskva: Prosveshchenie.

Zagladin, N.V. (2010). Vseobshchaja istorija. Istorija Novogo vremeni. XIX - nachalo XX veka: 8 klass [The World history. The Modern history. XIX - the beginning of the XX c.: 8-th grade]. Moskva: Russkoe slovo.

Zemlyanicyn, V.A. (2005). Frantsuzskaja politika korolevskogo doma Lankasterov [French politics of the House of Lancaster]: Doctor of Historical Sciences thesis abstract. Saint-Petrsburg: AIB. 